$\begin{array}{ll}\text { Variants } & \begin{array}{l}\text { Variants } \\ \text { The Journal of the European Society for Textual } \\ \text { Scholarship }\end{array}\end{array}$

15-16 | 2021

Textual Scholarship in the Twenty-First Century

\title{
Creative Concurrence. Gearing Genetic Criticism for the Sociology of Writing
}

Dirk Van Hulle

\section{(2) OpenEdition \\ Journals}

Electronic version

URL: https://journals.openedition.org/variants/1405

DOI: 10.4000/variants. 1405

ISSN: 1879-6095

\section{Publisher}

European Society for Textual Scholarship

Printed version

Date of publication: 1 July 2021

Number of pages: 45-62

ISSN: 1573-3084

\section{Electronic reference}

Dirk Van Hulle, "Creative Concurrence. Gearing Genetic Criticism for the Sociology of Writing", Variants

[Online], 15-16 | 2021, Online since 01 July 2021, connection on 13 September 2021. URL: http:// journals.openedition.org/variants/1405 ; DOI: https://doi.org/10.4000/variants. 1405 


\title{
Creative Concurrence. Gearing Genetic Criticism for the Sociology of Writing
}

Dirk Van Hulle

\begin{abstract}
This essay is an attempt to come to terms with a phenomenon that characterizes many authors' oeuvres: the concurrent composition of several works. My suggestion is to refer to this phenomenon as creative concurrence, drawing on experiences from two related disciplines, bibliography and the history of the book - notably D. F. McKenzie's "sociology of texts" and the concept of "concurrent production" - in order to cross-pollinate genetic criticism.
\end{abstract}

GENETIC CRITICISM HAS SO FAR WORKED WITH A MODEL - most explicitly put forward in Pierre-Marc de Biasi's functional typology of genetic documentation (Biasi 1996) — in which the so-called bon à tirer or the pass-for-press moment plays a crucial role. This is the moment the genesis generally moves from a private to a public enterprise ${ }^{1}$ Genetic criticism has traditionally focused on the so-called private component of the writing process, not so much on the public part, because that public genesis, according to Pierre-Marc de Biasi, follows a different logic:

The mutations of the avant-texte took place in a private writing domain where everything was possible at any time, including the complete extinction of the writing, even if the work seemed to be moving in the direction of a publishable text. By contrast, postpublication modifications are made in a public sphere where the book's reality cannot be ignored: they successively affect equally definitive textual versions of the "same" work, each of which can claim the status of a completely separate text each time, without it's [sic] being in general possible to recognize the logic of a process comparable to the pre-textual one between them.

(Biasi 1996, 40)

There is a historical explanation for this focus on the somewhat too black-andwhite dichotomy between the text and the so-called avant-texte, the writing process preceding the bon à tirer moment when the author decides the text is

1 The "Typology of Genetic Documentation" is presented as "a general table of the stages, phases, and operational functions that enable the classification of different types of manuscripts according to their location and status in the process of a work's production" (Biasi 1996 32; emphasis added). 
ready to be printed. In the first few decades of its existence, genetic criticism understandably emphasized its difference from related fields of study in order to establish itself as a discipline in its own right. Although this tendency is understandable, the downside is that there have been relatively few efforts (from the perspective of genetic criticism) to see how these related fields of study dealt with modern manuscripts. Thus, for instance, in The Study of Modern Manuscripts (1993), Donald H. Reiman distinguishes between private, confidential, and public documents, "based on the functions their authors intended them to play in communicating with specific intended readers" (Reiman 1993. xi). According to Reiman, "the primary factor that categorizes a manuscript as private, confidential, or public" is "the nature and extent of the writer's intended audience" (Reiman 1993, 65; emphasis in original): "A manuscript is private if its author intended it to be read only by one person or a specific small group of people whose identity he knew in advance; confidential if it was intended for a predefined but larger audience who may — or may not — be personally known to or interested in the author; and public only if it was written to be published or circulated for perusal by a widespread, unspecified audience" (Reiman 1993. 65; emphasis in original). Possible objections to Reiman's categorization are its exclusive reliance on authorial intention and the compartmentalization of a creative space that is fluid and uncompartmentalized by nature. But at least Reiman's suggestion adds nuance to a phenomenon that is treated rather implicitly in de Biasi's typology.

In its generality, de Biasi's more dichotomous understanding of a movement from private to public in creative composition is similar to an equally general statement in a related field of study, Bibliography, about another form of composition. In Bibliography, composition usually refers to the work of the compositor at the printer's. With reference to this type of composition in the early modern period, R. B. McKerrow had made the general claim that "for a printing house to be carried on economically there must be a definite correspondence between rate of composition and the output of the machine room" (qtd. in McKenzie 2002. 26, suggesting that the printing house functioned as a well-oiled machine, focusing on one book at a time. Donald F. McKenzie, however, explained how "McKerrow's valid general statement is transformed into an invalid particular statement", by looking more closely at the day-to-day business of specific printing houses. For instance, in his bibliographical study of the first sixteen years of Cambridge University Press, McKenzie concluded that a small printing house, "never using more than two presses, [...] habitually printed several books concurrently" (26). McKenzie was able to demonstrate that this principle of concurrent production "applied to virtually all book manufacture" (McDonald and Suarez in McKenzie 2002. 14).

Genetic criticism can benefit from McKenzie's insights in bibliography and book history. On the one hand, his notion of the sociology of texts can be an incentive to pay more attention (in genetic criticism) to the sociology of writing. And on the other hand, his notion of "concurrent production" can be a 
source of inspiration to examine a phenomenon that is understudied in genetic criticism: writers working on several projects simultaneously, which I propose to call "creative concurrence" and which cannot be studied without its diachronic counterpart: "creative recurrence".

These two principles of the "sociology of writing" and "creative concurrence and recurrence" are tied to each other in the sense that they both tend to challenge traditional forms of compartmentalization: the "sociology of writing" sees writing in terms of a collaborative ecology and therefore challenges any tendency to compartmentalize different agents of textual change, such as treating for instance the author as a self-contained unit, in isolation from editors, translators, typists, publishers and other agents of textual change; the notion of "creative concurrence" sees writing in terms of a textual ecology and therefore challenges any tendency to study every single work by an author as a self-contained textual unit, unrelated to their other works or to the oeuvre as a whole.

\section{The Sociology of Writing}

McKenzie's sociology of texts was mainly conceptualized on the basis of his study of early modern texts and printing houses, which explains the relative lack of engagement in genetic criticism with his work. As discussed above, according to de Biasi's rationale, the "different logic" of the postpublication phase sets it apart from the avant-texte (Biasi 1996, 40-41). In the meantime, however, these postpublication modifications have been recognized as part of a work's "epigenesis", the continuation of the genesis after publication (Van Hulle 2014). But there is another aspect in de Biasi's dichotomy that might need to be nuanced. Not only does the genesis often continue after publication, the public aspect of texts sometimes also precedes publication, especially in the case of pre-book publications. As a consequence, the creative process is often more "public" than generally assumed and therefore calls for some remodelling to accommodate the sociology of writing.

A good example in twentieth-century literature is the collaboration between Gordon Lish and Raymond Carver, the author of the short-story collection What We Talk About When We Talk About Love? Apparently, the minimalistic writing style Carver is famous for is actually to a large extent the work of his editor, Gordon Lish. As the fiction editor of the magazine Esquire from 1969 to 1977, Lish edited Carver's story "Neighbors" for publication in Esquire in 1971. The radical editing is considered to have had such an impact that it largely created the Carver style. As Tim Groenland notes in The Art of Editing, "Lish's mediating and gatekeeping activities" illustrate how "editors function as key players in the production of fiction" (Groenland 2019, xi). Carol Polsgrove describes how drastic the editorial intervention was: "On several pages of the twelve-page manuscript, fewer than half of Carver's words were left standing. Close to half were cut on several other pages"(Polsgrove 1995, 241). Lish's pruning was relentless, as his papers at the Lilly Library at Indiana University in Bloomington 
show. In some cases, one could even regard the result as a rewriting, and it does not come as a surprise, therefore, that the 2009 edition of the Collected Stories chose to publish some of the stories in both the edited and the unedited versions.

Playwrights often count on directors to help them give shape to the script, as the case of Alan Bennett and director Nicholas Hytner illustrates. For instance, in the spring of 1991, Bennett sent the first draft of his play The Madness of George III to Hytner to ask his feedback, as Hytner recalls in his memoirs: "It was based on fact. In 1788, George III apparently went mad. [... ] But in the spring of 1789, in the nick of time, the king seemed to come to his senses, so the Regency bill failed" (Hytner 2018, 117). Historical facts were important to Bennett, who had studied History at Oxford. On the other hand, Hytner's major concern was not historical truth but dramatic suspense: "I've never stopped pressing the claims of narrative tension, urging Alan to channel more of what he wants to say into dramatic action" (Hytner 2018, 120). Although, according to Hytner, Bennett "cooperated only up to a point" (Hytner 2018. 120), the Bennett papers at the Bodleian Library in Oxford (Bennet||1989-92, 588-89) suggest that he did revise his early versions quite drastically (especially the ending) due to comments made by both the director and the lead actors.

As McKenzie noted, "a book is never simply a remarkable object. Like every other technology it is invariably the product of human agency in complex and highly volatile contexts which a responsible scholarship must seek to recover if we are to understand better the creation and communication of meaning as the defining characteristic of human societies" (McKenzie 1999, 4). This insight has had quite an impact on textual scholarship and book history, and with some delay - also on literary studies more broadly. For instance, in Joyce studies. Whereas in 1977, Michael Groden suggested that the writing of Ulysses consisted of three stages (the development of an interior monologue technique; the abandonment of experimentation with the monologue for "a series parody styles"; and the creation of several new styles, followed by the revision of earlier episodes (Groden 1977, 4), a more recent textual approach replaces this threephase process by a five-phase scheme, importantly devoting a separate stage to the serialization: "(i) conception, (ii) drafting, (iii) serialization, (iv) continued post-serial drafting, and (v) the formation of plans for publication in volume form" (Hutton 2019. 74). This new attention to serialization as part of the writing process marks the increased attention to the sociology of texts, to a large extent thanks to McKenzie's Bibliography and the Sociology of Texts (1999) and Jerome McGann's work on the "socialization of the text" in The Textual Condition (1992).

Joyce's awareness of the "human agency" involved in his literary enterprises seems to be thematized in Finnegans Wake, where this agency is referred to as "the continually more and less intermisunderstanding minds of the anticollaborators" (Joyce 1939. 118.25). These textual agents range from typists, secretaries and amanuenses to proofreaders, patrons, journal editors, printers, champions, critics and even "enemies". Especially this latter, inimical category seems to 
have been a type of agency that sparked Joyce's creativity. In Joyce's case, the self-styled "enemy" par excellence was Wyndham Lewis, who asked Joyce for a contribution to his new journal The Enemy. Joyce obliged and submitted the piece, but Lewis then decided not to publish it. Moreover, in its stead he published his own critical "Analysis of the Mind of James Joyce". According to Lewis, Joyce had basically nothing to say; he was merely interested in "ways of doing things" rather than in "things to be done"; and he did not have any "special point of view, or none worth mentioning" (Lewis 1993. 88). Joyce's point of view in this matter seems to have been that "only the second-rate imagine that they have messages to deliver" (Banville 1989). He kept calm and carried on, cleverly using Lewis's poison to inoculate his own "work in progress" with it.

Joyce may be famous for his disrespect of publishers' and printers' general insistence on not making any changes at proof stage. Indeed, he often kept adding text wherever he found a white space in the margins. The ending of Ulysses, for instance, kept expanding to such an extent that it necessitated no less than four sets of placard proofs (Sullivan 2013. 179). But on other occasions, he did show great respect for printers, as the following textual tale illustrates. Partially in reply to Lewis, he wrote a fable, called "The Ondt and the Gracehoper", loosely based on Aesop's fable of the ant and the grasshopper, the Lewisian ant who saves up for winter and the spendthrift grasshopper who is associated with the Penman Joyce. The fable appeared several times in pre-book publications (Van Hulle 2016. 143ff.) and expanded with every new version. It ends with a poem, which was originally fairly short, consisting of only 12 lines. When it was first published in the magazine transition (March 1928), it had 18 lines. The fable subsequently came out as part of Tales Told of Shem and Shaun in a deluxe edition by The Black Sun press (1929), run by Harry and Caresse Crosby. At proof stage, it had ten extra lines, 28 in total, and it was to expand even further, resulting in 34 lines when the book appeared. This accretion was partially due to the printer. In her memoir, Caresse Crosby mentions an "unexpected incident" relating to the master printer Roger Lescaret during the production of Tales Told of Shem and Shaun:

The pages were on the press and Lescaret in consternation pedaled over to the rue de Lilly to show me, to my horror, that on the final "forme", due to a slight error in his calculations, only two lines would fall en plaine [sic] page - this from the typographer's point of view was a heinous offense to good taste. What could be done at this late date! Nothing, the other formes had all been printed and the type distributed (we only had enough type for four pages at a time). Then Lescaret asked me if I wouldn't beg Mr. Joyce to add another eight lines to help us out. I laughed scornfully at the little man, what a ludicrous idea, when a great writer has composed each line of his prose as carefully as a sonnet you don't ask him to inflate a masterpiece to help out the printer!

(Crosby 1953 187; see also Ellmann 1983. 614-15) 
But that was exactly what the "great writer" did. Behind Crosby's back, Lescaret secretly went to Joyce, asked him if he could write a few extra lines, and Joyce indeed produced the requested lines. Evidently, if Finnegans Wake can be considered a masterpiece, that is not only thanks to "anticollaborators" such as Roger Lescaret, but they did play an active role in the creative development of the work in progress.

Later in the writing process of Finnegans Wake, Joyce even outsourced his reading. Thus, he asked Samuel Beckett to read a book that was sent to him by Heinrich Zimmer Jr., called Maya: Der indische Mythos (1938). Beckett made notes for Joyce on three pages, preserved at the University at Buffalo (Van Hulle 1999. 143ff.). Joyce also involved his friends in collective notetaking, as Stuart Gilbert's Paris journal entry on a reading session in preparation of Haveth Childers Everywhere shows: "Five volumes of the Encyclopaedia Britannica on his sofa. He has made a list of 30 towns, New York, Vienna, Budapest, and Mrs. Fleischman has read out the articles on some of these" (Gilbert 1993, 20-21). Gilbert was irked by the way Joyce, "curled on his sofa", kept on "pondering puns" while exploiting his friends, such as Padraic Colum, Helen Fleischman, Paul Léon, Lucia Joyce, and Gilbert himself 2 Gilbert gives the example of the word "Slotspark", which became "Slutsgartern" in Finnegans Wake (Joyce 1939, 532.22-23): "Thus 'Slotspark' (I think) at Christiania becomes Sluts' park. He collects all queer names in this way and will soon have notebooks full of them" (Gilbert 1993. 20-21). In his journal, Gilbert ventilated his resentment: "With foreign words it's too easy. The provincial Dubliner. Foreign equals funny" (Gilbert 1993. 21 ), thus giving voice - albeit in the privacy of his personal journal — to the social tensions involved in Joyce's literary corporation, in which he assumed the entrepreneurial role of CEO. This image is at a far remove from the private enterprise of the writing process as it is presented in de Biasi's model. Evidently, this model is a conscious generalisation, as de Biasi readily admits, but now that genetic criticism exists more than fifty years, the time seems propitious to refine the model and find a place for the sociology of writing in genetic criticism.

\section{Creative Concurrence}

A second way in which I would like to suggest a remodelling is related to the phenomena of creative concurrence and recurrence. Traditionally, genetic criticism tends to approach an author's oeuvre work by work. It would be useful to also consider a work's genesis within the development of the author's oeuvre in its entirety, and consider all the geneses of its components, including vestigial notes, drafts and unpublished works, constituting the sous-œuvre - not so much in Thomas C. Connolly's general sense of the marginalized parts of a work that

2 "I 'finish' Vienna and read Christiania and Bucharest. Whenever I come to a name (of a street, suburb, park, etc.) I pause. Joyce thinks. If he can Anglicize the word, i.e. make a pun on it, Mrs. F. records the name of its deformation in the notebook" (Gilbert 1993 20-21; qtd. in Van Hulle 2016 163) 
are traditionally eclipsed (Connolly 2018), but in the sense of the entire oeuvre's genetic dossier.

The focus on separate works is understandable, given the complexity of most literary works' geneses. The reality for many writers, however, is that they divide their time between multiple book projects on a daily basis. For instance, as Vincent Neyt has shown ${ }^{3}$ the genesis of Stephen King's novel IT cannot be studied in isolation. In the period of seven years between 1980, when King started the first draft of IT, and 1986, the year the novel was published, King published no less than thirteen books, some of them under the pseudonym Richard Bachman $4^{4}$ This was possible because King regards writing as a craft, which requires a certain discipline. Every day, he tries to write half a dozen of pages, and in the afternoon or evenings, he tends to revise another work, often to meet a scheduled submission deadline. These deadlines, imposed by the publisher, are a significant social element in the writing process, either as an incentive or as a form of pressure that can stifle creativity. As a consequence, there are constantly several book projects underway concurrently. Analogous to McKenzie's principle of concurrent production, I therefore suggest we introduce a principle of concurrent writing or creative concurrence in genetic criticism, which implies reconstructing the everyday reality of how a work, in all its draft versions, interacted with the other works that populated the author's writing desk at any given moment.

Creative concurrence does not necessarily have a sociological dimension. A writer can simply be working on several projects at the same time. But often a social aspect does play a role. To illustrate just how interwoven the geneses of an author's individual works can be, it is useful to have a brief look at Samuel Beckett's writing desk in the late 1970s. He was already working on a longer piece of prose, called Company, when he received a commission. In the fall of 1977, the English actor David Warrilow requested Beckett to write "a monologue on death", to which Beckett replied on 1 October with the line "My birth was my death" (Beckett 2016, 471 note 1). The next day, under the preliminary title "Gone", he immediately started developing the theme: as soon one is born, one starts dying. Thus began what was to become A Piece of Monologue, translated into French as Solo (Pilling 2016. 205). On a piece of paper, Beckett wrote some loose jottings on the theme of death, such as "Not much left to die" and "Dead \& gone / Dying \& going" (UoR MS 2460, m28, 01v; qtd. in Van Hulle 2019. 75). Some of the more concrete stage settings clearly presage A Piece of Monologue, such as this idea for the "End: fade out general light. Hold on globe. Fade out

3 Vincent Neyt is currently working on a PhD on the genesis of King's IT at the University of Antwerp.

4 One work of non-fiction, called Danse Macabre (1981); one collection of four novellas (Different Seasons (1982)); a collection of short stories (Skeleton Crew (1985)) and ten novels, some of them under a pseudonym: Firestarter (1980), Cujo (1981), Roadwork (1981 — as Richard Bachman), The Gunslinger (1982), The Running Man (1982 — as Richard Bachman), Christine (1983), Pet Sematary (1985), The Talisman (1984 - with Peter Straub), Thinner (1984 — as Richard Bachman), The Eyes of the Dragon (1984). 
globe." And this one for the opening: "Fade up. 10". 'Birth.' 10"." (UoR MS 2460, m28, 01v; qtd. in Van Hulle 2019. 75) The note "Birth was his death. Etc." clearly echoes Beckett's letter to Warrilow. The difference is that the narrative voice has changed from a first-person to a third-person narrator. This change marks an interesting turn in Beckett's late work for the theatre, which tends to present itself as staged narratives, or what Matthijs Engelberts has termed récit scénique (Engelberts 2001, 211-12). In the case of this opening sentence, the third-person narrative adds depth and ambiguity, because the sentence "Birth was his death" (which was to become "Birth was the death of him" in the published version of $A$ Piece of Monologue) leaves open the possibility that the protagonist's birth meant the death of someone else. In the case of the author himself, who was born on Good Friday 1906, that "someone else" was Jesus Christ, whose suffering on the cross therefore always marked Beckett's birthday - a concurrence that never stopped leaving an imprint, also on his works.

The note "Birth was his death. Etc." is not dated, but on the back of the piece of paper, Beckett drafted a poem ("fleuves et océans") that is dated "Ussy Toussaint 77", that is, 1 November 1977. The next day, on 2 November 1977, he told Jocelyn Herbert he was "taking it very easy through 2 prose pieces underway - snail like - one very limited in scope and ambition, the other I hope to keep me going (company) for the duration" (Beckett 2016, 471). As Beckett's pun indicates, Company was the longer text that was keeping him company, the shorter one was A Piece of Monologue. Beckett does not even mention the poem, but the manuscripts indicate that, on 1 November 1977, Beckett was working on at least three literary projects in three different genres at the same time: poetry, prose and drama. The commissioned piece of monologue clearly had a thematic impact on the poem's content, as the opening lines already indicate, playing as they do with the standard expression "ils l'ont laissé pour mort" (they left him for dead): "fleuves et océans / l'ont laissé pour vivant" (rivers and oceans / have left him alive) (Beckett 2012, 217). So life ('vivant') is, again, presented as a process of dying. This is a clear case of creative concurrence, materialized on the recto and verso sides of one single scrap of paper (UoR MS 2460, m18, 01r and 01v; qtd. in Van Hulle 2019. 72).

The concurrence between the drafts of Company and A Piece of Monologue even became a form of confluence at some point, however briefly. After having been working on both projects concurrently for about eight months, Beckett tried on 17 May 1978 to insert this excerpt from A Piece of Monologue into Company, as paragraph 54, written without errors or revisions. Here, the pronoun ('you') is different yet again, less ambiguous this time:

Birth was the death of you. At close of day. Sun sunk behind the larches. Needles turning green. Light dying in the room. Soon none left to die. No. No such thing as no light. Dies on the dawn \& never dies. Slowly in the dark a faint hand. It holds high a lighted spill. In light of spill faintly the hand \& milkwhite globe. Second hand. In light of spill. It lifts off globe \& 
disappears. Reappears empty. Lifts off chimney. Two hands \& chimney in light of spill. Spill to wick. Chimney back on.

(BDMP 9. EM, 25r)

To make this confluence possible, however temporarily, Beckett decided to leave out four sentences from the dramatic fragment, because they all related to the act of looking (Engelberts 2001, 211). But then again, Beckett soon decided that this confluence did not work after all, and he cancelled the paragraph with a large St. Andrew's cross.

In the end, the three concurrent projects were published separately: A Piece of Monologue, Company and the poems as part of the mirlitonnades. But the creative concurrence still shows in the theme of life as a form of dying, "his" birth thus being both the death of the protagonist and that of Christ. The biographical link is even more explicit in Company than in A Piece of Monologue, both of which were written while Deirdre Bair was preparing her biography of Beckett 5 "You first saw the light of day the day Christ died" (Beckett 2009. 9).

Sometimes, the creative concurrence can materialize in a single document, such as a notebook. Beckett's so-called "Eté 56" Notebook is a good example ("Eté 56" because that is what Beckett has written on its cover). The very idea of identifying his notebook with a period (summer 1956) rather than giving it a title (as he did in other cases, such as the "Molloy" Notebooks or the "Whoroscope" Notebook), suggests the remarkable concurrence of several projects at this point in time. To be correct, the notebook also contains drafts that were written later than the Summer of 1956, but several drafts do testify to the concurrence of various literary projects in the same creative space. As a physical environment, the notebook serves as a creative ecology. It contains notes and drafts pertaining to several works, as Beckett retrospectively noted on the front flyleaf: the play Fin de partie, the radio play All That Fall, the play Krapp's Last Tape, the prose work Comment c'est, the play Happy Days (BDMP 3, 'Eté 56' Notebook). And he even forgot to mention the radio play Words and Music. The back of the notebook also contains an attempt to design the typography of a title page for his radio play Embers. As this list already indicates, the creative concurrence in this notebook involves an interesting generic interaction between prose writing and dramatic texts, but also between media (as the notebook also contains notes and texts for the radio medium).

Even if the temporal coincidence is not preserved in one particular document, it is possible to observe the impact of creative concurrence and its relevance to genetic criticism. Writers often allude to their previous works, creating a so-called "intratextual" network of references, a set of "links established by a reader between at least two texts written by the same author" (Martel 2005, 93). To see how concurrent writing on different projects can result in intratextual interference across versions, the winter of 1957-58 is a particularly interesting juncture. In the late fall of 1957, Beckett was struggling with the translation of

$5 \quad$ Bair's bibliography was published on 14 September 1978; see Pilling 2016 207. 
his own novel L'Innommable into English, and so he interrupted his translation to write a first draft of a radio play, Embers. At that moment (10 December 1957), the BBC broadcast a fragment from Beckett's novel Molloy, read by Patrick Magee. Beckett was struck by the actor's voice, but the transmission was not ideal. While Beckett temporarily abandoned his work on the radio play and continued translating L'Innommable 6 he went to the BBC studios in Paris where they played a recording of Magee's reading. This was probably the first time Beckett saw a tape-recorder, which prompted him to start writing the play Krapp's Last Tape (originally called "Magee Monologue") even before the end of his translation of L'Innommable - which he finished when he was three days into the writing process of Krapp's Last Tape (Van Hulle 2015. 138-50).

But that is still just concurrent writing in general, chronological terms. If we look at the texts, we see that this creative concurrence has a direct intratextual effect on the content of these works. A notebook at Harvard University's Houghton Library (BDMP 7. HU MS THR 70.3) contains an early version of the radio play Embers ${ }^{7}$ which can be read as an inquiry into the workings of the human mind that was inspired partly by listening to Patrick Magee's readings of the Molloy fragments (10 December 1957) ${ }^{8}$ and From an Abandoned Work for the BBC 9 But Embers was also inspired by the act of translating L'Innommable. In the manuscript of The Unnamable, just before "Basil is becoming important" and the narrator decides to "call him Mahood instead" (BDMP 2. EN1, 21r), the first-person narrator describes his own voice, which — he says - was "like the sea":

I strained my ear towards what must have been my own voice still, so weak, so far, that it was like the sea, a calm distant sea far calm sea dying no, none of that, no beach, no shore, the sea is enough, I've had enough of shingle, enough of sand, enough of earth, enough of sea too.

(BDMP 2. EN1, 21r; emphasis added)

While Beckett was making this translation, he started writing Embers, which opens with the directions: "Sea scarcely audible. Henry's boots on shingle" (Beck-

6 In his manuscript of The Unnamable, Beckett marked this moment on page 23v of the second notebook, referring to Embers as "Henry \& Ada": "Reprise 21.1.58 après échec de Henry et Ada" ["Taken up again 21.1.58 after failure of Henry and Ada"] (BDMP 2. EN2, 23v).

7 This early English version of the radio play Embers starts on folio 10r in the form of a dialogue between "He" and "She", which ends on page 20r.

8 On 11 December 1957 Beckett wrote to Donald McWhinnie at the BBC: "I was in Paris last night and there listened to "Molloy". Reception execrable, needless to say, but I got enough, knowing the text so well, to realize the extraordinary quality of Magee's performance." (Beckett 2014b 77)

9 In the same letter of 11 December, Beckett wrote he was "hoping to get it clearer on Friday, and on Saturday FAAW [From an Abandoned Work] which I am waiting for with acute curiosity" (Beckett 2014b 77-78). 
ett 1959, 20). Here, the creative concurrence obviously had a direct intratextual impact.

But there were also intertextual connections that were partly triggered by concurrence ${ }^{10}$ The opening directions of Embers with the sea in the background and the boots on the shingle recall the Joycean image of Stephen Dedalus walking on Sandymount strand in the "Proteus" episode of Ulysses. At this point, one might object that this is reading too much Joyce into the text. But when we look at the chronology of Beckett's day-to-day business, we see that he had just been reading Joyce's letters shortly before he started writing Embers 11 and that, after interrupting this writing process and taking Embers up again, he read Stanislaus Joyce's book My Brother's Keeper, about which he reported to Con Leventhal on 29 February 1958 (Van Hulle and Nixon 2013. 39). Beckett thus seems to have been reminded of Joyce's famous experiment with the interior monologue in Ulysses, where Stephen closes his eyes to concentrate on the "ineluctable modality of the audible" (episode 3). In Embers, Beckett chose a similar setting to give a new, equally experimental shape to the Joycean stream of consciousness, concentrating on the audible in the "'blind" radio medium" (Beloborodova and Verhulst 2018. 251).

And there is more going on at the same time. Next to this watery connection to the sea, another element that connects the different concurrent creative projects is fire. In A Portrait of the Artist as a Young Man and later in Ulysses, Joyce had made his protagonist refer to Percy Bysshe Shelley's fading coal as a metaphor for "the mind in creation": "In the intense instant of imagination, when the mind, Shelley says, is a fading coal" (Joyce 1986, 9.380). The reference highlights only the first part of Shelley's comparison. In the second part of the famous "Defence of Poetry", Shelley interestingly suggests a hint of linguistic skepticism, thereby presaging Fritz Mauthner's Sprachkritik, which fascinated both Joyce and Beckett:

the mind in creation is as a fading coal, which some invisible influence, like an inconstant wind, awakens to transitory brightness; this power arises from within, like the colour of a flower which fades and changes as it is developed $[\ldots]$. Could this influence be durable in its original purity and force, it is impossible to predict the greatness of the results: but when composition begins, inspiration is already on the decline; and the most glorious poetry that has been communicated to the world is probably a feeble shadow of the original conceptions of the poet.

(Shelley 1977, 505)

10 I use the notion of "intertextuality", as opposed to "influence" (which only looks at interaction between authors without taking the reader into account), in the sense of Michael Riffaterre's definition of intertextuality as "the reader's experience of links" between different works (Riffaterre 1980, 4), with the explicit proviso that this also includes genetically informed readers.

11 Faber had sent him "Joyce's letters" according to a letter to Barbara Bray (18 September 1957) and a month later he wrote to Thomas MacGreevy that he had been "reading his letters" (Pilling 2016, 137). 
The moment of inspiration may awaken the coal's brightness, but as soon as the poet starts putting it into words the coal increasingly transforms into the state of embers and ashes, which suggests a link with Beckett's lifelong fascination with the ineluctable modality of the ineffable. One of the intertextual elements in Beckett's work that illustrate this fascination is his favourite line from Petrarch, which he used to quote by heart: "Chi può dir com' egli arde é in picciol foco" (Atik 2001, 80). In Beckett's own translation: "He who knows he is burning is burning in a small fire"; or in an older translation by John Nott: "Faint is the flame that language can express" (Atik 2001. 80). In other words, if you can still put it into words, it can always get worse. Beckett used these "faint fires" in his translation of L'Innommable: "Je ne dois mon existence à personne, ces lueurs ne sont pas de celles qui éclairent ou brûlent" (Beckett 1953. 13) / "I owe my existence to nobody, these faint fires are not of the kind those that illuminate or burn" (BDMP 2. EN, 04r). During the process of translating L'Innommable, Beckett worked on the first manuscript version of Embers - which on its last page tellingly contains the words "the fire gone" (BDMP 7). HU MS THR 70.3, 20r) - and the first version of Krapp's Last Tape, in which the fire (symbolizing creative power) is a key theme. When Beckett discussed the play with the actor for whom he had written it (Patrick Magee) he wrote: "While I think of it a word to be brought out very strong is 'burning' (page 7, line 1), in order that 'fire' at the end may carry all its ambiguity" (Beckett 2014b, 129). Beckett is here referring to a particular typescript, on which he replaced the word "panting" by "burning": "drowned in dreams and panting burning to be gone" (BDMP 3. ET5, 07r). The ambiguity Beckett mentions is the tension between the wish to die (burning to be gone) and the creative fire of the artist Krapp when he was still younger, full of himself and "burning" to write his magnum opus. This cluster of meanings was contained in that one line from Petrarch, as Beckett explained in a letter to Con Leventhal shortly after the composition of Krapp's Last Tape: after quoting the line from Petrarch, he writes that he understands "arde" not in the sense of ardent lovers' burning desire but "more generally, and less gallantly, than in the Canzoniere":

As thus solicited it can link up with the $3^{\text {rd }}$ proposition (coup de grâce) of Gorgias in his Nonent:

1. Nothing is

2. If anything is, it cannot be known.

3. If anything is, and can be known, it cannot be expressed in speech.

Beckett 2014b 136)

As this letter indicates, Beckett seems to have had a particular interpretation of Petrarch's line in mind, which focused on linguistic scepticism. Applied to Krapp, the Petrarchan subtext suggests that he who can say he is burning (the middle-aged Krapp on the tape, the artist as a younger man full of himself with "the fire in [him] now," convinced that he is going to write a magnum opus worth leaving his love for) is burning in a small fire. 
All these faint fires find their place in Beckett's work almost concurrently in the winter of 1957-58, when Beckett is simultaneously working on his translation of L'Innommable, his first attempt at writing Embers, and Krapp's Last Tape (which is then followed by another bout at writing Embers, so that Krapp's Last Tape can be said to have been written as an entr'acte in the genesis of Embers). The intratextual connection between the faint fires in these works is triggered by an intertextual link with Petrarch. Beckett had been reading Petrarch as a student: his twovolume edition of Le Rime del Petrarca contains numerous marginalia and student notes (indicating for instance the rhyme scheme of some of the sonnets), but remarkably enough, his favourite line is not marked (Petrarca 1824). This raises the question why Petrarch suddenly enters the scene at this particular moment in 1958. Most probably, the trigger was actually another author. Beckett's personal library contains a 1958 edition of Michel de Montaigne's Essais. In his second essay, De la Tristesse, Montaigne quotes precisely this line from Petrarch (Montaigne 1958. 32). In and of itself, this Pléiade edition's publication in 1958 does not necessarily corroborate the potential connection with Beckett's output in the same year. To establish this connection, it may be useful to confront creative concurrence with another important force to be reckoned with in genetic criticism: creative recurrence.

\section{Creative Recurrence}

To examine the genesis of one particular work, it is often necessary to zoom out and include the rest of the cuvre and the sous-œuvre, both backward and forward in time. In retrograde direction, as indicated above, Beckett's knowledge of Petrarch dated back to his student days in the 1920s at Trinity College, Dublin, where he studied French and Italian literature. In the 1930s, he made copious notes on philosophy, with a special interest in the Presocratics. Under the heading "Gorgias of LeONTINI in Sicily (483-375)" he noted:

Three celebrated propositions -

1. Nothing exists.

2. If it did, it could not be known.

3. If it could be known, it could not be communicated. (In his On Nature, or, The Non-Existent)

All opinions equally false.

(TCD MS 10967/48; qtd in Feldman 2009. 76)

As the above-mentioned letter to Con Leventhal shows, twenty-five years after Beckett noted this down among his Philosophy notes, Gorgias's propositions "had lost little relevance to Beckett" (Feldman 2009. 76).

Looking forward in time, Beckett's "Nonent"-related reading of his favourite line brings Petrarch's statement closer to another one of Beckett's favourite lines, this time from Shakespeare's King Lear: "The worst is not / So long as one can 
say, This is the worst" (qtd. in Van Hulle 2010. UoR MS 2910, 14v). Again the underlying idea is similar: as long as you can still say it, it can always get worse. This line is jotted down in a much later notebook from the 1970s (the so-called "Sottisier" Notebook), and is the starting point for Worstward Ho, a work Beckett wrote in the 1980s. In another notebook from the 1980s, he jotted down this reading trace: "Curae leves loquuntur, ingentes stupent (Seneca)" (Light sorrows speak, deeper ones are silent.) (BDMP 1. UoR MS 2934, f. 01r). Seneca is not part of Beckett's personal library in Paris. But there is a noteworthy connection with the same Pléiade edition of Montaigne's Essais. The quote from Seneca appears in the same second essay, De la Tristesse, on page 33, the page facing the one that contains the quotation from Petrarch. This diachronical axis of recurrent preoccupations meets the synchronic axis of creative concurrence in early 1958, giving us a sense of the various literary projects that were lying on Beckett's desk at the same time, and thus mutually impacted on each other.

\section{Conclusion}

As mentioned above, now that genetic criticism exists more than fifty years, the time seems propitious to refine de Biasi's model and find a place for both the sociology of writing and creative concurrence/recurrence in genetic criticism. The details of the examples above should not prevent us from seeing the wood for the trees. They provide us with the particulars to remodel the complex relationship between private and public, which has perhaps too easily been oversimplified as a general dichotomy, and which has in that capacity played a central role in genetic criticism for several decades. As in McKenzie's refutation of McKerrow's general statement (quoted above), the details of everyday life in an author's writing practice can transform a valid general statement into an invalid particular statement. As discussed above, in many cases, the text can already become public before the bon à tirer moment, for instance through pre-book publications. And social events, such as commissions, can lead to periods of creative concurrence, which is not included in de Biasi's scheme as its implied focus is on single works as items of study, relatively isolated from the rest of the oeuvre 12

To some extent, such a work-by-work approach may have been conditioned by the print paradigm, which has had consequences for scholarly editing. Due to the limited space, a printed edition often necessarily presents a literary oeuvre

12 For instance, he defines the collection of genetic documentation [dossier de genèse] as "the whole body of known, classified, and transcribed manuscripts and documents connected with a text whose form has reached, in the opinion of its author, a state of completion or near completion" (Biasi 1996, 31; emphasis added). The "Typology of Genetic Documentation" is presented as "a general table of the stages, phases, and operational functions that enable the classification of different types of manuscripts according to their location and status in the process of $a$ work's production" (Biasi 1996. 32; emphasis added). 
as a set of works, represented by a critically edited text and accompanied by annotations and a critical apparatus; and due to the codex format, the individual works are often contained in separate volumes. As a result, the writer's complete works appear as a sum of parts. By means of introductions and annotations, the editor usually has to remedy this by explaining that the oeuvre also constitutes a Gestalt, a whole that is greater than the sum of its parts. A Gestalt however, is not only greater than, but also different from, the sum of its parts. As Caroll Pratt writes in the introduction to Wolfgang Köhler's The Task of Gestalt Psychology, it is a common error to leave out the word "different" and simply define a Gestalt as "the whole is more than the sum of the parts" (Pratt 1969. 9). This definition mistakenly ignores that a relationship between the parts is itself something that is not present in the individual parts themselves (Pratt 1969, 10). If all the parts of a bike are laid out on the floor of a bike shop, for instance, they still do not make up the bike. Only when the parts are assembled and come to take up a specific relation to each other, do they become something different, that is, a bike. If, in the digital age, we treat the oeuvre as a Gestalt to develop a digital complete works edition that is truly complete, we need to think inclusively about the entirety of genetic dossiers relating to an author's works, both published and unpublished, providing tools for advanced chronological searches into both the synchrony and the diachrony of the sous-oeuvre, in which creative concurrence and recurrence play a significant role.

\section{Bibliography}

Aтıк, Anne, 2001. How It Was: A Memoir of Samuel Beckett. London: Faber \& Faber.

Banville, John, December 1989. "Waiting for the Last Word." The Observer page 36 .

Beckett, SAmuel, 1953. L'Innommable. Paris: Les Éditions de Minuit.

1959. Krapp's Last Tape and Embers. London: Faber and Faber.

, 2009. Company, Ill Seen Ill Said, Worstward Ho, Stirrings Still, edited by Dirk Van Hulle. London: Faber and Faber.

, 2011. BDMP 1 - Stirrings Still / Soubresauts and Comment dire / what is the word (digital genetic edition), The Beckett Digital Manuscript Project, volume 1, edited by Dirk Van Hulle and Vincent Neyt. Brussels: University Press Antwerp. Available from: http://www. beckettarchive.org

(Accessed: 2020-06-17).

2012. Collected Poems, edited by Seán Lawlor and John Pilling. London: Faber and Faber. 
, 2014a. BDMP 2 - L'Innommable / The Unnamable (digital genetic edition), The Beckett Digital Manuscript Project, volume 2, edited by Dirk Van Hulle, Vincent Neyt, and Shane Weller. Brussels: University Press Antwerp. Available from: http://www. beckettarchive.org (Accessed: 2020-06-17).

, 2014b. The Letters of Samuel Beckett (1957-1965), volume 3, edited by George Craig, Martha Dow Fehsenfeld, Dan Gunn, and Lois More Overbeck. Cambridge: Cambridge University Press.

, 2015. BDMP 3 - Krapp's Last Tape / La Dernière Bande (digital genetic edition), The Beckett Digital Manuscript Project, volume 3, edited by Dirk Van Hulle and Vincent Neyt. Brussels: University Press Antwerp. Available from: http://www beckettarchive.org (Accessed: 2020-06-17).

, 2016. The Letters of Samuel Beckett (1966-1989), volume 4, edited by George Craig, Martha Dow Fehsenfeld, Dan Gunn, and Lois More Overbeck. Cambridge: Cambridge University Press.

- 2018. BDMP 7 - Fin de partie / Endgame (digital genetic edition), The Beckett Digital Manuscript Project, volume 7, edited by Dirk Van Hulle, Shane Weller, and Vincent Neyt. Brussels: University Press Antwerp. Available from: http://www. beckettarchive.org

- 2020. BDMP 9 - Company / Compagnie (digital genetic edition), The Beckett Digital Manuscript Project, volume 9, edited by Dirk Van Hulle, Vincent Neyt, and Georgina Nugent-Folan. Brussels: University Press Antwerp. Available from: http://www . beckettarchive.org (Accessed: 2020-06-17).

Beloborodova, Olga and Pim Verhulst, 2018. "Broadcasting the mind: extended cognition in Beckett's radio plays." In Beckett and Modernism, edited by Olga Beloborodova, Pim Verhulst, and Dirk Van Hulle, Basingstoke: Palgrave, pages 239-57.

Bennet, Alan, 1989-92. "Play scripts for The Madness of George III, 1989-1992."

Biasi, Pierre-Marc de, 1996. "What is a Literary Draft? Toward a Functional Typology of Genetic Documentation." Yale French Studies 89, pages 26-58.

Carver, Raymond, 2009. Collected Stories, edited by William Stull and Maureen Carroll. New York City (NY): Library of America.

Connolly, Thomas C., 2018. Paul Celan's Unfinished Poetics: Readings in the Sous-CEuvre. Cambridge: Legenda.

Crosby, Caress, 1953. The Passionate Years: An Autobiography. New York (NY): The Dial Press.

Ellmann, Richard, 1983. James Joyce. Oxford: Oxford University Press, new and revised edition edition. 
Engelberts, Matthijs, 2001. Défis du récit scénique: Formes et enjeux du mode narratif dans le théâtre de Beckett et Duras. Geneva: Librarie Droz.

Feldman, Matthew, 2009. Beckett's Books: A Cultural History of the Interwar Notes. London: Continuum.

Gilbert, Stuart, 1993. Reflections on James Joyce: Stuart Gilbert's Paris Journal, edited by Thomas Staley and Randolph Lewis. Austin (TX): University of Texas Press.

Groden, Michael, 1977. 'Ulysses' in Progress. Princeton (NJ): Princeton University Press.

Groenland, Tim, 2019. The Art of Editing: Raymond Carver and David Foster Wallace. London: Bloomsbury.

Hutton, Clare, 2019. Serial Encounters: 'Ulysses' and 'The Little Review'. Oxford: Oxford University Press.

Hytner, Nicholas, 2018. Balancing Acts: Behind the Scenes at the National Theatre. London: Vintage.

Joyce, James, 1939. Finnegans Wake. London: Faber \& Faber.

— 1986. Ulysses, edited by Hans Walter Gabler, Wolfhard Steppa, and Claus Melchior. London: Vintage.

Lewis, Wyndham, 1993. Time and Western Man, edited by Paul Edwards. Santa Rosa (CA): Black Sparrow Press.

Martel, KareEn, 2005. “Les notions d'intertextualité et d'intratextualité dans les théories de la réception." Protée 33(1), pages 93-102.

McGann, Jerome, 1992. The Textual Condition. Princeton (NJ): Princeton University Press.

McKenzie, D. F., 1999. Bibliography and the Sociology of Texts. Cambridge: Cambridge University Press.

- 2002. Making Meaning: 'Printers of the Mind' and Other Essays, edited by Peter D. McDonald and Michael F. Suarez, S. J. Amherst (MA): University of Massachusetts Press.

Montaigne, Michel de, 1958. Essais. Paris: Gallimard Pléiade.

Petrarca, Francesco, 1824. Le Rime del Petrarca. Milan: Nicolò Bettoni,.

Pilling, John, 2016. A Samuel Beckett Chronology. Houndmills: Palgrave Macmillan. 
Polsgrove, CArol, 1995. It Wasn't Pretty, Folks, But Didn't We Have Fun? Esquire in the Sixties. New York (NY): W. W. Norton.

Pratt, Caroll C., 1969. "Introduction." In The Task of Gestalt Psychology, authored by Köhler, Wolfgang, Princeton (NJ): Princeton University Press, pages 3-32.

Reiman, Donald, 1993. The Study of Modern Manuscripts. Baltimore (MD): John Hopkins University Press.

Riffaterre, Michael, 1980. “La Trace de l'intertexte.” Pensée 215, pages 4-18.

Shelley, Percy Bysshe, 1977. Shelley's Poetry and Prose, edited by Donald H. Reiman and Sharon B. Powers. New York (NY): Norton.

Sullivan, Hannah, 2013. The Work of Revision. Cambridge (MA): Harvard University Press.

VAN Hulle, Dirk, 1999. “Beckett, Mauthner, Zimmer, Joyce.” Joyce Studies Annual pages 143-83.

— 2010. "Beckett and Shakespeare on Nothing, or Whatever Lurks behind the Veil." Beckett 1. Available from:

http://www.limitebeckett.paris-sorbonne.fr/one/vanhulle.html (Accessed: 2020-08-13).

- 2014. Modern Manuscripts: The Extended Mind and Creative Undoing from Darwin to Beckett and Beyond. London: Bloomsbury.

— 2015. The Making of Samuel Beckett's 'Krapp's Last Tape' / 'La Dernière Bande'. London: Bloomsbury.

- 2016. James Joyce's 'Work in Progress': Pre-Book Publications of 'Finnegans Wake' Fragments. Studies in Publishing History: Manuscript, Print, Digital.

New York (NY): Routledge.

— 2019. "Beckett's Art of the Commonplace: The 'Sottisier' Notebook and mirlitonnades Drafts." Journal of Beckett Studies 28(1), pages 67-89.

Van Hulle, Dirk and Mark Nixon, 2013. Samuel Beckett's Library. Cambridge: Cambridge University Press. 